\title{
Proteomic analysis of the ila2 mutant of Arabidopsis links translational regulation with photosynthesis, protein folding and ribosomal proteins
}

\author{
Isabel Faus ${ }^{1} \cdot$ Regina Niñoles ${ }^{1} \cdot$ Susana Tárraga ${ }^{1} \cdot$ Jose Gadea $^{1}$ \\ Received: 29 October 2019 / Revised: 16 December 2019 / Accepted: 25 March 2020 / Published online: 31 March 2020 \\ (c) Franciszek Górski Institute of Plant Physiology, Polish Academy of Sciences, Kraków 2020
}

\begin{abstract}
A key component of the conserved GCN (General Control Non-repressive) signalling pathway in plants is the ILITHYIA(ILA) protein, homologous to the yeast GCN1 protein. Similar to yeast and animals, ILA seems to be involved in the activation of the eIF2 $\alpha$ kinase GCN2, allowing protein arrest under stress conditions. Recently, it has been reported that, in plants, ILA could be also playing a role in development independent of GCN2. To gain insight into this new function of the ILA protein, we have performed proteomic analysis to identify differentially-expressed proteins in the strong loss-of-function allele of ILA (ila2). ila2 plants present a reduced expression of photosynthetic proteins, and an increased expression of the translational initiation factor eiF5A, ribosomal proteins and heat-shock proteins. These results open new hypothesis to understand the roles of this important translational regulator in plant tissues.
\end{abstract}

Keywords Proteomics · Translational regulation · Protein folding · GCN1 · Photosynthesis

\section{Introduction}

Eukaryotic cells employ complex mechanisms to regulate protein synthesis at multiple levels. Control of translational initiation, that requires only hours to take effect, provides cells with a mechanism to rapidly induce or repress synthesis of specific proteins. This is especially important for plants, which must quickly respond to changing environmental conditions.

Communicated by P. Wojtaszek.

Isabel Faus and Regina Niñoles contributed equally to this work.

Electronic supplementary material The online version of this article (https://doi.org/10.1007/s11738-020-03047-7) contains supplementary material, which is available to authorized users.

Jose Gadea

jgadeav@ibmcp.upv.es

1 Instituto de Biología Molecular Y Celular de Plantas (IBMCP), Universitat Politècnica de València (UPV)-Consejo Superior de Investigaciones Científicas (CSIC), Ciudad Politécnica de La Innovación (CPI), Ed. 8E, C/Ingeniero Fausto Elio s/n, 46022 Valencia, Spain
A major signalling pathway for stress responsive translational control is the one mediated by the conserved protein kinase GCN2 (for General Control Non-repressive). This signalling pathway enables yeast cells to sense and overcome amino acid deprivation (Hinnebusch 2005). Upon activation of this kinase, the $\alpha$ subunit of the initiation factor eIF2 is phosphorylated and inhibited because it stays bound to the guanine nucleotide exchange factor eIF2B. As eIF2 is essential for loading a tRNA onto the $40 \mathrm{~S}$ ribosome, overall translation initiation is arrested, while allowing the selective translation of the transcription factor GCN4. A GCN2 kinase exists in all plant species studied so far, and eIF $2 \alpha$ is phosphorylated by many situations in a GCN2-dependent manner, including amino-acid deprivation stresses such as glyphosate treatment (Zhang et al. 2008; Faus et al. 2015). However, recent data by Izquierdo et al. (2018) argue against P-eIF2 $\alpha$ involvement in the general abolition of protein synthesis. Besides, the absence of a GCN4-like transcription factor in the Arabidopsis genome or the lack of susceptibility of $g c n 2$ mutants to this and other abiotic stresses support the idea of a minor relevance of GCN2 and P-eIF $2 \alpha$ regulation in plants under stress.

A key component of this signalling pathway is the protein GCN1, necessary in yeast and animals for eIF $2 \alpha$ phosphorylation. GCN1 promotes GCN2 activation by 
uncharged t-RNAs by positioning GCN2 on the ribosome (García-Barrio et al. 2000). In Arabidopsis, ILITHYIA (ILA) is the only protein in the genome presenting high similarity to GCN1. Consistent with the model, ILA(GCN1) binds GCN2 in Arabidopsis, and ila/gcn1 mutants are not able to phosphorylate eIF2 $\alpha$ (Wang et al. 2017; Faus et al. 2018). However, the behaviour in gcn2 and ila/gcnl mutants differ under several abiotic stress situations. gcn 2 and wild-type seedlings are unaffected by mitochondrial dysfunction or boric acid, whereas both treatments lead to leaf yellowing and growth inhibition in ilalgcn1. Moreover, ilalgcnl mutant is more susceptible to Pseudomonas infection than wild-type and gcn2 (Izquierdo et al. 2018). This indicates that ILA/GCN1 acts independent of GCN2 is stress situations and open a new pathway for translational regulation, governed by this protein, in plants.

Interestingly, the phenotypic differences between gcn2 and ila/gcnl mutant extend to aspects of plant development. The weak alleles, like ila3, present leaf yellowness when grown in soil (Monaghan et al. 2010), have problems in chloroplast biogenesis and root development, and a dramatic alteration of its transcriptome at the seedling stage (Faus et al. 2018). The strong alleles, like ila2, are smaller than the wild-type, have yellow serrated leaves, and root growth and chloroplast deficiencies, and must be propagated as heterozygotes (Monaghan et al. 2010). This contrasts with the phenotype of gcn2 mutants, which are indistinguishable of wild-type. All this indicates that ILA/GCN1 also acts independent of GCN2 in developmental processes. Transcriptomic analysis of the weak ila3 allele showed a clear downregulation of genes related to photosynthesis, and a reduced expression of many genes involved in different aspects of defence responses, which would explain its susceptibility to biotic attacks. In opposite, antioxidant defences, protein folding, (marked by the increased expression of heat shock proteins (HSP), Lon proteases, responsible for the degradation of unstable proteins, and categories involving translation and RNA modification were enriched in ila3 (Faus et al. 2018).

To gain a deeper understanding of the role of the ILA protein on plant development, a 2-D differential gel electrophoresis (2-DIGE) comparative proteomic assay to identify proteins differentially-expressed between wildtype and ila2 seedlings was performed. Our results extend and complement the data obtained by transcriptomic for the weak ila 3 allele. The data confirm the link between ila developmental phenotypes and a correct ribosome assembly and protein cell homeostasis, as revealed by the differential expression of several heat-shock proteins and ribosomal proteins. Moreover, they confirm the chloroplasts defects of ila mutants, suggested by phenotypic and transcriptomic data.

\section{Materials and methods}

\section{Sample material}

Wild-type Col 0 and ila2 (SALK_149084) lines were used in this study. ila2 was obtained from NASC and genotyped using the insertion-flanking primers $5^{\prime}$-TGTTAGCCTCAG TCAAGTAC-3' and 5'-ATAGCCAGCTTCCCTTTCTC-3'. Seeds were sowed in $0.4 \%$ MS Salts agar plates, $1 \%$ sucrose, $\mathrm{pH}$ 5.7, and grown at $23{ }^{\circ} \mathrm{C}$ with a 16-h-light/8-h-dark cycle for up to three weeks for ila2 (two weeks for wild-type) and equal-sized seedlings were collected for protein extraction.

\section{Protein extraction and labelling}

Seedlings were ground in liquid nitrogen and resuspended in $50 \mathrm{mM}$ Tris $\mathrm{pH} 7.5,1 \mathrm{mM}$ PMSF, $0.2 \% \beta$-mercaptoethanol and centrifuged for $20 \mathrm{~min}$. 1\% Trichloroacetic acid (TCA) was added to supernatant at $1: 1 \mathrm{v} / \mathrm{v}$. and incubated for $1 \mathrm{~h}$. Samples were centrifuged for $20 \mathrm{~min}$ and washed three time with cold acetone.

Equal amounts $(50 \mu \mathrm{g})$ of protein samples were labelled using CyDyes DIGE fluors (Cy2, Cy3 and Cy5). Four replicates of wild-type and ila2 were labelled in a dye-swap experiment using Cy3 and Cy5. A pooled sample containing all samples used in the experiment was labelled with Cy2 for internal control. Lysis buffer was added to make up the volume to $40 \mathrm{~mL}$. Then, the pool was mixed with $40 \mu \mathrm{L}$ of isoelectrofocusing (IEF) rehydration buffer ( $8 \mathrm{M}$ urea, $4 \%$ CHAPS, $0.005 \%$ bromophenol blue) containing $65 \mathrm{mM}$ DTT and $1 \%$ IPG buffer $\mathrm{pH} 3-11$, and it was loaded in the gel.

\section{D-electrophoresis}

24-cm long strip with an immobilized $\mathrm{pH}$ gradient of 3-11 were hydrated overnight at room temperature with $450 \mu \mathrm{L}$ of IEF rehydration buffer, containing the reagents Destreak and Pharmalyte, $\mathrm{pH} 3-10$. The CyDyes-labelled pool sample $(150 \mu \mathrm{g})$ was loaded on the hydrated strip. IEF was performed in an IPGphor unit at $20^{\circ} \mathrm{C}$ and at a maximum current of $50 \mathrm{~mA}$ per strip at the following settings: $300 \mathrm{~V}$ for $1 \mathrm{~h}$, an increasing voltage gradient to $1000 \mathrm{~V}$ for $6 \mathrm{~h}$, an increasing voltage gradient to $8000 \mathrm{~V}$ for $3 \mathrm{~h}$, before finally holding at $8000 \mathrm{~V}$ for a total of $32,000 \mathrm{Vh}$. After IEF, the strip was equilibrated separately for $15 \mathrm{~min}$ in $10 \mathrm{~mL}$ equilibration solution I ( $0.05 \mathrm{M}$ Tris-HCl buffer, $\mathrm{pH} 8.8$, containing $6 \mathrm{M}$ urea, $30 \%$ glycerol, $2 \%$ SDS, $2 \%$ DTT), followed by equilibration solution II ( $0.05 \mathrm{M}$ Tris-HCl buffer $\mathrm{pH} 8.8$, containing $6 \mathrm{M}$ urea, $30 \%$ glycerol, $2 \% \mathrm{SDS}, 2.5 \%$ iodoacetamide, $0.01 \%$ bromophenol blue) before being applied to the second dimension $12.5 \%$ SDS-PAGE gels. Gels were run at 
$20^{\circ} \mathrm{C}$ by applying $2 \mathrm{~W} / \mathrm{gel}$ for $30 \mathrm{~min}$ and $20 \mathrm{~W} / \mathrm{gel}$ for the remaining $6 \mathrm{~h}$ in an Ettan DALT six unit. A running buffer of $25 \mathrm{mM}$ Tris, $\mathrm{pH} 8.3,192 \mathrm{mM}$ glycine and $0.2 \%$ SDS was used.

\section{Data analysis}

Proteins were visualized using a Typhoon Trio scanner. The three images of each gel were processed with DIA (Differential in-gel analysis). DIA module was used for the spot detection, spot volume quantification and volume-ratio normalization of different samples in the same gel.

Protein spots that showed at least two-fold change in abundance between control and infected material and statistical significance using a Student's $t$ test $(p<0.05)$ were considered differentially expressed.

\section{Protein identification}

Protein identification was performed by the Proteomic Service of the Universitat de Valencia. Spots of interest were excised from silver-stained gel, distained by $2-5$ min washes with acetonitrile $(\mathrm{ACN})$ :water $(1: 1)$ and rehydrated with $50 \mathrm{mM}$ ammonium bicarbonate for $5 \mathrm{~min}$ and $25 \mathrm{mM}$ ammonium bicarbonate in 50\% (v/v) ACN for $15 \mathrm{~min}$. Samples were digested with $10 \mathrm{ng}$ trypsin $\left(50 \mathrm{mM} \mathrm{NH}_{4} \mathrm{HCO}_{3}, \mathrm{pH}\right.$ $7.8 ; 5 \mathrm{mM} \mathrm{CaCl} 2 ; 12.5 \mathrm{ng} / \mu \mathrm{L})\left(\mathrm{o} / \mathrm{n}\right.$ at $\left.37{ }^{\circ} \mathrm{C}\right)$.

The digestion was stopped with $7 \mathrm{~mL}$ of $0.1 \%$ Trifluoroacetic acid (TFA), and $1 \mu \mathrm{L}$ was spotted onto the MALDI target plate. After air-drying the droplets at room temperature, $0.5 \mu \mathrm{L}$ of matrix ( $5 \mathrm{mg} / \mathrm{mL}$ CHCA) ( $\alpha$-cyano- 4 hydroxycinnamic acid, Sigma) in $0.1 \%$ TFA-ACN/ $\mathrm{H}_{2} \mathrm{O}(1: 1$, $\mathrm{v} / \mathrm{v}$ ) was added and allowed to air-dry at room temperature. A 4700 Proteomics Analyzer was used for analyzing the resulting mixtures. Five of the most intense precursors (according to the threshold criteria: minimum signal-tonoise: 10 , minimum cluster area: 500, maximum precursor gap: 200 ppm, maximum fraction gap: 4) were selected for every position for the MS/MS analysis. The MS/MS data were acquired using the default $1 \mathrm{kV}$ MS/MS method and the MS and MS/MS information was sent to Protein Pilot v5.0 software. Protein assignment was achieved via BLASTtx, choosing those proteins with similarity over $90 \%$ based on sequence homology. The samples without a positive identification were analyzed by LC/MS/MS. Peptide separation was performed using an Ultimate nano-LC system and a QSTAR XL Q-TOF hybrid mass spectrometer. Samples $(5 \mu \mathrm{L})$ were delivered to the system using a FAMOS autosampler at $30 \mu \mathrm{L} / \mathrm{min}$, and peptides were trapped onto a PepMap C18 pre-column $(5 \mathrm{~mm} \times 300 \mathrm{~mm}$ i.d.). Peptides were then eluted onto the PepMap C18 analytical column $(15 \mathrm{~cm} \times 75 \mathrm{~mm}$ i.d. $)$ at $300 \mathrm{~nL} / \mathrm{min}$ and were separated using a 30 min gradient of 5-45\% ACN. QSTAR
$\mathrm{XL}$ was operated in the information-dependent acquisition mode, in which a 1-s TOF MS scan from 400 to $2000 \mathrm{~m} / \mathrm{z}$ was performed, followed by 3 -s product ion scans from 65 to $2000 \mathrm{~m} / \mathrm{z}$ on the three most intense doubly or triply charged ions. The MS/MS information was sent to ProteinPilot.

\section{Results and discussion}

\section{D-DIGE analysis reveals differentially-expressed proteins between wild-type and ila2 seedlings}

To investigate the impact that the loss-of-function of the ILA protein could provoke in Arabidopsis, the strong allele ila2 was selected for comparison with wild-type. In this allele, a T-DNA is inserted in the 22nd exon of the gene, generating a non-functional protein without the C-terminal part (Monaghan et al. 2010). The strong phenotypes associated with this mutant (small size, yellow colour in emerging leaves, sterility in homozygous) confirm that the lack of this protein is affecting essential aspects of plant development. Given that the ILA protein has been involved in translational regulation, a comparative proteomic assay between wild-type and ila 2 seedlings will determine, first, to which extend the translational ability of the cells is affected in ila2, and second, will highlight the main effects of ILA loss-of-function. To avoid confusion due to the different developmental stages of the two genotypes, equal size, and not equal age, seedlings of wild-type and ila 2 were selected for protein extraction.

A side by side comparison of the 2D-DIGE images representing wild-type and ila2 seedlings, as well as a composite image of both, is shown in Fig. 1a. A total of 1537 spots could be detected in this experiment, according to the DeCyder 2D software. The 2-DE profiles had a similar distribution pattern of spots in wild-type and ila2. In fact, only 125 spots $(8.13 \%)$ were detected as differentially expressed between both genotypes, without an apparent bias towards any of them, with 81 more abundant in wild-type samples, and 44 more abundant in ila2 samples. (Supplemental Table 1). Assuming that some of the spots will presumably resolve the same protein, reflecting different isoforms or posttranslational modifications (Carmona et al. 2019), the number of differentially expressed proteins between the two genotypes is expected to be even lower. These results indicate that the lack of ILA is not rendering a general arrest of protein translation in this mutant and that most cellular proteins needed for basic cellular functions are present in ila2. Besides, it indicates that protein accumulation in ila2 is adjusted to the particular needs of this genotype, discarding an essential role of ILA in general aspects of the protein translation machinery.

As an initial approach to the nature of the differentiallyexpressed spots, eighteen of them were excised from 
A
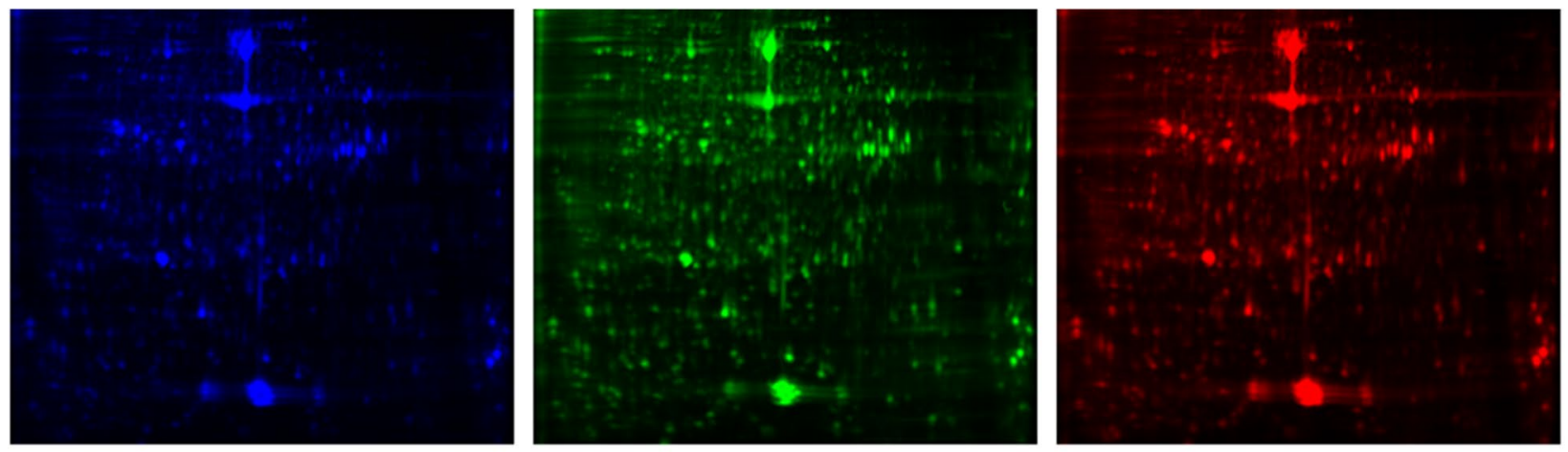

B
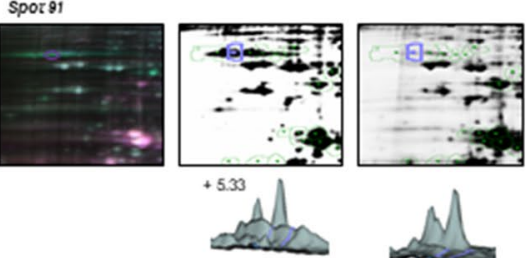

Spoz 1097

\section{Spor 681}
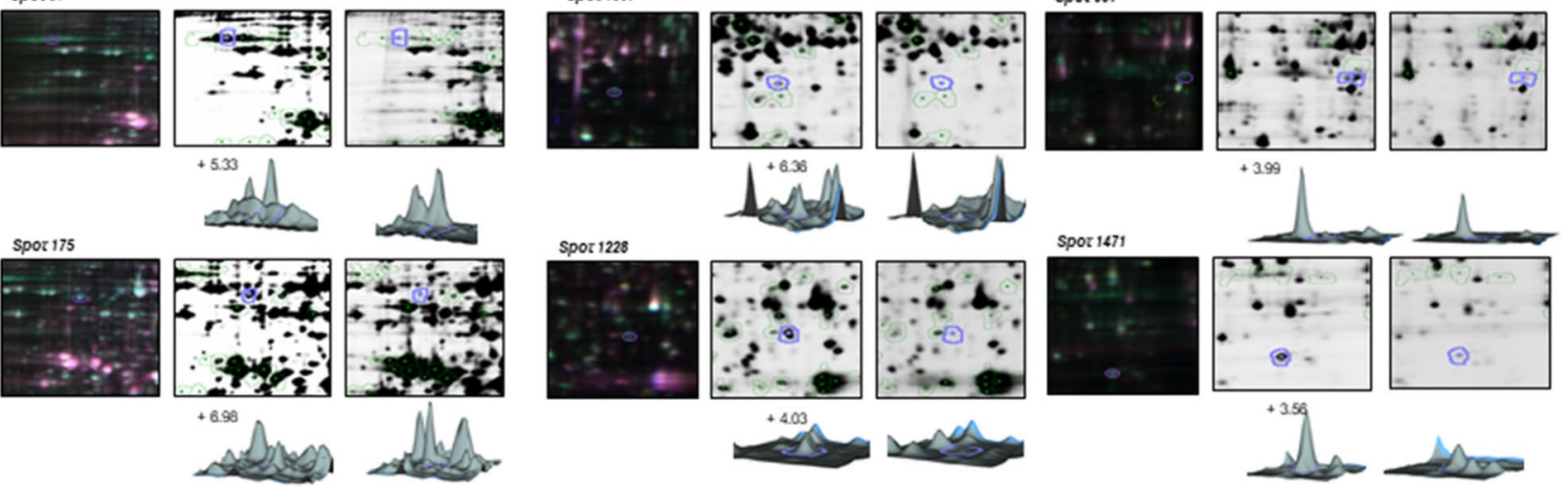

$+4.03$
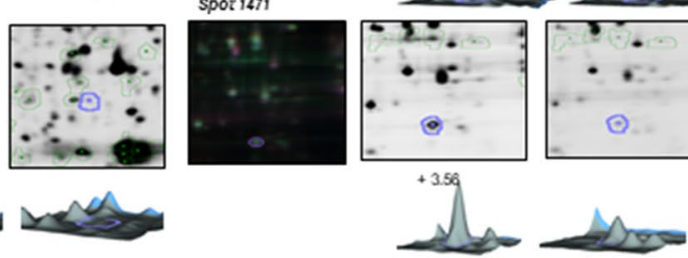

Fig. 1 2D-DIGE fluorescent labelled proteins. a Representative sideby-side comparison of gel images showing the differentially-labelled proteins from wild-type (Cy5) and ila2 samples (Cy3), as well as pooled sample used for comparison (Cy2). b Differentially-expressed spots between wild-type and ila2 seedlings are shown. Those that

2D-PAGE gels and subjected to identification via peptidemass fingerprinting with MALDI-TOF-MS after homology search using ProteinPilot software (Table 1). For the selection, we mainly focused on the most differentially-expressed spots according to Supplemental Table 1, avoiding the very proximal or very faint ones. Six representative ila2 overexpressed spots are displayed in Fig. 1b.

\section{Down-regulated proteins in ila2 confirm chloroplast and photosynthesis defects}

ila mutants are defective in chlorophyll content and photosynthesis capacity (Monaghan et al. 2010; Faus et al. 2018). Moreover, chloroplasts of both the weak ila 3 and the strong ila2 alleles present a poorly developed thylakoid membrane network, indicating a general defect in chloroplast biogenesis and function. This idea is reinforced by some of the proteins found differentially-expressed in ila2. Among the proteins with decreased protein expression in the mutant plants are carbonic anhydrase (CA1; At3g01500), and Rubisco activase (RCA; At2g39730). CA1 catalyzes the reversible hydration of $\mathrm{CO}_{2}$ in higher plant tissues (DiMario et al. 2017). RCA regulates Rubisco function by facilitating the dissociation of were selected for extraction and MS analysis are marked with white circles. Volumetric quantification of representative spots of interest identified. Abundance values are expressed as the ratio obtained from volumetric image comparisons (ila2/wild-type)

inhibitory sugar phosphates from the active site of Rubisco in an ATP-dependent manner (Portis et al. 2008). Additionally, other chloroplast proteins were found less expressed in ila2 tissues, such as the PSII subunit PSBQ-2 (At4g05180), the small Rubisco subunit RBCS1A (At1g67090), the Calvin cycle intermediate phosphoribulokinase (At1g32060) and the Ferredoxin-NADP(+)-oxidoreductase 2 FNR2. Altogether, these results reinforce the observed chloroplastic defects of ila mutants and anticipate a putative cause of their defective plant development. The effects of a reduced level of FNR on plant development and on the structure and function of the photosynthetic machinery has been reported, fnr mutants presenting stunted growth and pale green leaves (Lintala et al. 2012). Similarly, mutants plants in the CA1 gene are smaller than the wild-type, and their development is strongly retarded (Fromm et al. 2016). Interestingly, and similar to ila2, plants lacking the two isoforms of the translation initiation eIFiso4G (i4gl and $i 4 g 2$ ) display a defective phenotype that includes poor growth, lower chlorophyll levels, chloroplasts with lower grana stacking and lower fertility (Lellis et al. 2010; Chen et al. 2014). eIF4 factors interact with the mRNA and the 40S ribosome to assemble the preinitiation complex. Similar to ila2, those plants present a 
Table 1 List of differentially accumulated proteins identified between wild-type and ila2 seedlings

\begin{tabular}{|c|c|c|c|c|c|c|c|}
\hline Spot no. & Ratio ila2/wt & Acc. num & Protein pilot score & AGI name & Gene name & Prot. annotation & Functional classification \\
\hline 175 & 6.98 & $\begin{array}{l}\text { splQ8GUM2IHSP7I_ } \\
\text { ARATH }\end{array}$ & 119.49 & At4g37910 & HSP70-9 & Heat shock protein & Molecular chaperone \\
\hline 1097 & 6.36 & $\begin{array}{l}\text { splQ9FDZ9|RL212_ } \\
\text { ARATH }\end{array}$ & 4.01 & At1g57660 & RPL21E & 60S ribosomal protein & Ribosomal protein \\
\hline 91 & 5.33 & $\begin{array}{l}\text { splP51818lHS903 } \\
\text { ARATH }\end{array}$ & 39.68 & At5g56010 & HSP90-3 & Heat shock protein & Molecular chaperone \\
\hline 1228 & 4.03 & $\begin{array}{l}\text { splQ03250|RBG7_ } \\
\text { ARATH }\end{array}$ & 26.22 & At2g21660 & GRP7 & $\begin{array}{l}\text { Glycine-rich RNA- } \\
\text { binding protein }\end{array}$ & $\begin{array}{l}\text { RNA transcription or } \\
\text { processing during } \\
\text { stress }\end{array}$ \\
\hline 661 & 3.99 & $\begin{array}{l}\text { splP49227|RL52_ } \\
\text { ARATH }\end{array}$ & 53.33 & At5g39740 & RPL5B & $60 \mathrm{~S}$ ribosomal protein & Ribosomal protein \\
\hline 1471 & 3.56 & $\begin{array}{l}\text { splQ8RXU5IR37A2 } \\
\text { ARATH }\end{array}$ & 7.83 & At3g60245 & RPL37AC & $60 \mathrm{~S}$ ribosomal protein & Ribosomal protein \\
\hline 873 & 3.54 & $\begin{array}{l}\text { splQ8H156IRAN3 } \\
\text { ARATH }\end{array}$ & 31.12 & At5g55190 & RAN3 & $\begin{array}{l}\text { GTP-binding nuclear } \\
\text { protein }\end{array}$ & $\begin{array}{l}\text { Nucleocytoplasmic } \\
\text { transport }\end{array}$ \\
\hline 1308 & 3.08 & $\begin{array}{l}\text { splQ93VR4IML423_ } \\
\text { ARATH }\end{array}$ & 27.13 & At1g24020 & MLP423 & MLP-like protein & $\begin{array}{l}\text { Abscisic acid signalling } \\
\text { pathway }\end{array}$ \\
\hline 1174 & 2.67 & $\begin{array}{l}\text { splQ93VP3IIF5A2_ } \\
\text { ARATH }\end{array}$ & 15.96 & At1g26630 & ELF5A-2 & $\begin{array}{l}\text { Eukaryotic transla- } \\
\text { tion initiation factor } \\
5 \mathrm{~A}-2\end{array}$ & Protein biosynthesis \\
\hline 243 & 2.21 & $\begin{array}{l}\text { splQ8L7B5|CH60B_ } \\
\text { ARATH }\end{array}$ & 131.94 & At2g33210 & HSP60-2 & Heat shock protein & Molecular chaperone \\
\hline 435 & 2.13 & $\begin{array}{l}\text { splQ9LUT2IMETK4_ } \\
\text { ARATH }\end{array}$ & 59.85 & At3g17390 & METK4 & $\begin{array}{l}S \text {-Adenosylmethionine } \\
\text { synthase } 4\end{array}$ & $\begin{array}{l}\text { Lignin biosynthetic } \\
\text { process }\end{array}$ \\
\hline 664 & -5.12 & $\begin{array}{l}\text { splQ8W493|FNRL2_ } \\
\text { ARATH }\end{array}$ & 37.48 & At1g20020 & FNR2 & $\begin{array}{l}\text { Ferredoxin-NADP } \\
\text { reductase }\end{array}$ & Photosynthesis \\
\hline 927 & -3.43 & $\begin{array}{l}\text { sp|P27140|BCA1_- } \\
\text { ARATH }\end{array}$ & 33.18 & At3g01500 & BCA1 & $\begin{array}{l}\text { Beta carbonic anhy- } \\
\text { drase }\end{array}$ & Photosynthesis \\
\hline 1289 & -3.24 & $\begin{array}{l}\text { splQ41932IPSBQ2_ } \\
\text { ARATH }\end{array}$ & 52.82 & At4g05180 & PBSQ2 & $\begin{array}{l}\text { Photosystem II } \\
\text { subunit }\end{array}$ & $\begin{array}{l}\text { Photosystem II assem- } \\
\text { bly }\end{array}$ \\
\hline 702 & -3.16 & $\begin{array}{l}\text { splQ96262|PCAP1_ } \\
\text { ARATH }\end{array}$ & 12.92 & At4g20260 & PCAP1 & $\begin{array}{l}\text { Plasma membrane- } \\
\text { associated cation- } \\
\text { binding protein }\end{array}$ & $\begin{array}{l}\text { Response to abiotic } \\
\text { stress }\end{array}$ \\
\hline 498 & -3.15 & $\begin{array}{l}\text { splP25697|KPPR } \\
\text { ARATH }\end{array}$ & 60.83 & At1g32060 & PRK & Phosphoribulokinase & $\begin{array}{l}\text { Calvin cycle, photosyn- } \\
\text { thesis }\end{array}$ \\
\hline 882 & -2.24 & $\begin{array}{l}\text { splP10795|RBS1A_ } \\
\text { ARATH }\end{array}$ & 26.01 & At1g67090 & RBCS-1A & $\begin{array}{l}\text { Ribulose bisphosphate } \\
\text { carboxylase small } \\
\text { chain }\end{array}$ & $\begin{array}{l}\text { Calvin cycle, photosyn- } \\
\text { thesis }\end{array}$ \\
\hline 427 & -2.22 & $\begin{array}{l}\text { splP10896|RCA_ } \\
\text { ARATH }\end{array}$ & 55.12 & At2g39730 & RCA & RubisCO activase & Activation of $\mathrm{RuBisCO}$ \\
\hline
\end{tabular}

reduced expression of CA1, RCA and PSBQ. In summary, the link between chloroplast missfunction and defective plant development is strengthened by the low expression of chloroplastic proteins in ila2. Moreover, the results obtained for $i 4 \mathrm{~g}$ and also for ila 2 open a connexion between protein translation and chloroplast development.

\section{Ribosomal proteins and heat-shock proteins are more expressed in ila2 mutants}

Remarkable, most of the identified proteins with increased protein expression in the ila 2 mutant plants belong to two clear functional categories. Three heat-shock proteins, HSP90-3 (At5g56010), HSP70-9 (At4g37910) and HSP60-2 (At2g33210) were more increased in ila2. The spot identified as HSP70-9 (spot 1751) was the most differentially-expressed (6.98 fold), and the one identified as HSP90-3 (spot 91) is very proximal to five more spots $(85,90,92,93$ and 99) which follow the same trend of expression in ila2, suggesting that at least some of them could be the isoforms HSP90-2 and HSP90-4 proteins (Krishna et al. 2001) or post-translational modifications of HSP90s (Mollapour et al. 2012) (supplemental Fig. 1). This indicates that ila2 plants are constitutive subjected to 
an internal stress condition where protein folding is disturbed. Interestingly, Faus et al. (2018) already reported an increase of HSP mRNAs in the weak allele ila3 (Faus et al. 2018), reinforcing the idea of folding defects in ila plants. Curiously, among the proteins identified as more expressed in an ila2 background, a 36\% (4 out of 11) belong to the category of protein translation. One of them is the eiF5A-2 translational factor. eIF5 interacts with the 40S initiation complex to mediate hydrolysis of eIF2-GTP, a critical step in initiation complex formation, as the release of multiple eIFs, including eIF2-GDP, is necessary for the recruitment of 60S ribosomal subunit (Sharma et al. 2016). GCN1 facilitates the activation of eiF2 $\alpha$ kinase GCN2, which upon phosphorylation of eiF2 $\alpha$, blocks eIF2-GTP hydrolysis (García-Barrio et al. 2000). Therefore, a non-functional GCN1 protein in ila2 will not allow GCN2 to inhibit translation via eiF $2 \alpha$ phosphorylation. The overexpression of the eiF5 factor in ila2 plants suggest that this initiation factor could compensate the defect in the GCN2-regulated inhibition of protein translation. In this regard, it has been reported that the effect of eIF2 phosphorylation can be mimicked by eIF5 overexpression, which turns eIF5 into translational inhibitor, thereby promoting the translation of GCN4 in yeast (Singh et al. 2006) and ATF4 in Drosophila (Kozel et al. 2016). For the first time, this evidences a similar mechanism orchestrating in plants, although the existence of GCN4/ATF4-like genes in Arabidopsis is unknown.

In addition, three ribosomal proteins, RPL21E (At1g57860), RPL5B (At5g39740) and RPL37A2 (At3g60245) were also overexpressed in ila2. Disturbance of ribosome biogenesis by distinct external and/or internal stimulations, (like malfunction of genes required for this process), results in ribosomal stress, leading to accumulation of ribosome-free form of RPs (Zhou et al. 2015). These results suggest that, under certain conditions or developmental stages, ILA1 could play a role in ribosome assembly, and its loss-of-function causes protein folding stress and free ribosomal protein accumulation, that will eventually perform ribosome independent functions (Zhou et al. 2015). Again, this is the first evidence of ILA affecting ribosomal stress and accumulation of RPs.

In conclusion, these results suggest that ILA is a central player in GCN2-mediated and GCN2-independent protein translation and ribosome assembly, and its loss-of-function causes a decrease in photosynthesis proteins, protein folding stress and free ribosomal protein accumulation.

Author contribution statement IF and RN performed the experiments. ST performed protein analysis. Jose Gadea and Regina Niñoles design the experiment. José Gadea wrote the manuscript.
Acknowledgements This work was partially funded by the Dirección General de Universidades e Investigación (Grant number BFU2011-22526).

\section{References}

Carmona L, Alquézar B, Tárraga S, Peña L (2019) Protein analysis of moro blood orange pulp during storage at low temperatures. Food Chem 277:75-83

Chen Z, Jolley B, Caldwell C, Gallie DR (2014) Eukaryotic translation initiation factor eIFiso4G is required to regulate violaxanthin De-epoxidase expression in Arabidopsis. J Biol Chem 289(20):13926-13936

DiMario RJ, Clayton H, Mukherjee A, Ludwig M, Moroney JV (2017) Plant carbonic anhydrases: structures, locations, evolution, and physiological roles. Mol Plant 10(1):30-46

Faus I, Zabalza A, Santiago J, Nebauer SG, Royuela M, Serrano R, Gadea J (2015) Protein kinase GCN2 mediates responses to glyphosate in Arabidopsis. BMC Plant Biol 15:14

Faus I, Niñoles R, Kesari V, Llabata P, Tam E, Nebauer SG, Santiago J, Hauser MT, Gadea J (2018) Arabidopsis ILITHYIA protein is necessary for proper chloroplast biogenesis and root development independent of eIF $2 \alpha$ phosphorylation. J Plant Physiol 224-225:173-182

Fromm S, Braun HP, Peterhansel C (2016) Mitochondrial gamma carbonic anhydrases are required for complex I assembly and plant reproductive development. New Phytol 211(1):194-207

Garcia-Barrio M, Dong J, Ufano S, Hinnebusch A (2000) Association of GCN1-GCN20 regulatory complex with the N-terminus of eIF2 $\alpha$ kinase GCN2 is required for GCN2 activation. EMBO J 19:1887-1899. https://doi.org/10.1093/emboj/19.8.1887

Hinnebusch AG (2005) Translational regulation of GCN4 and the general amino acid control of yeast. Annu Rev Microbiol 59:407-450

Izquierdo Y, Kulasekaran S, Benito P, López B, Marcos R, Cascón T, Hamberg M, Castresana C (2018) Arabidopsis nonresponding to oxylipins locus NOXY7 encodes a yeast GCN1 homolog that mediates noncanonical translation regulation and stress adaptation. Plant Cell Environ 41(6):1438-1452

Kozel C, Thompson B, Hustak S et al (2016) Overexpression of eIF5 or its protein mimic 5MP perturbs eIF2 function and induces ATF4 translation through delayed re-initiation. Nucleic Acids Res 44(18):8704-8713. https://doi.org/10.1093/nar/gkw559

Krishna P, Gloor G (2001) The Hsp90 family of proteins in Arabidopsis thaliana. Cell Stress Chaperones 6(3):238-246

Lellis AD, Allen ML, Aertker AW, Tran JK, Hillis DM, Harbin CR, Caldwell C, Gallie DR, Browning KS (2010) Deletion of the eIFiso4G subunit of the Arabidopsis eIFiso4F translation initiation complex impairs health and viability. Plant Mol Biol 74(3):249-263

Lintala M, Lehtimäki N, Benz JP, Jungfer A, Soll J, Aro EM, Bölter B, Mulo P (2012) Depletion of leaf-type ferredoxin-NADP(+) oxidoreductase results in the permanent induction of photoprotective mechanisms in Arabidopsis chloroplasts. Plant J 70(5):809-817

Mollapour M, Neckers L (1823) (2012) Post-translational modifications of Hsp90 and their contributions to chaperone regulation. Biochim Biophys Acta 3:648-655. https://doi.org/10.1016/j.bbamc r.2011.07.018

Monaghan J, Li X (2010) The HEAT repeat protein ILITYHIA is required for plant immunity. Plant Cell Physiol 51(5):742-753

Portis AR Jr, Li C, Wang D, Salvucci ME (2008) Regulation of Rubisco activase and its interaction with Rubisco. J Exp Bot 59(7):1597-1604 
Sharma DK, Bressler K, Patel H, Balasingam N, Thakor N (2016) Role of eukaryotic initiation factors during cellular stress and cancer progression. J Nucleic Acids 2016:8235121

Singh CR, Lee B, Udagawa T, Mohammad-Qureshi SS, Yamamoto Y, Pavitt GD, Asano K (2006) An eIF5/eIF2 complex antagonizes guanine nucleotide exchange by eIF2B during translation initiation. EMBO J 25:4537-4546

Wang L, Li H, Zhao C, Li S, Kong L, Wu W, Kong W, Liu Y, Wei Y, Zhu JK, Zhang H (2017) The inhibition of protein translation mediated by AtGCN1 is essential for cold tolerance in Arabidopsis thaliana. Plant Cell Environ 40(1):56-68

Zhang Y, Wang Y, Kanyuka K, Parry MA, Powers SJ, Halford NG (2008) GCN2-dependent phosphorylation of eukaryotic translation initiation factor-2alpha in Arabidopsis. J Exp Bot 59(11):3131-3141

Zhou X, Liao WJ, Liao JM, Liao P, Lu H (2015) Ribosomal proteins: functions beyond the ribosome. J Mol Cell Biol 7(2):92-104. https ://doi.org/10.1093/jmcb/mjv014

Publisher's Note Springer Nature remains neutral with regard to jurisdictional claims in published maps and institutional affiliations. 